\title{
PEMANFAATAN KOMPOS BLOK LIMBAH KULIT KOPI SEBAGAI MEDIA TANAM
}

\section{(the Utilization of Coffee Pulp and Coffee Husk Compost Block as Growing Media)}

\author{
Elida Novita ${ }^{1}$, Anis Fathurrohman ${ }^{1}$, Hendra Andiananta Pradana ${ }^{2}$ \\ ${ }^{1}$ Jurusan Teknik Pertanian, Fakultas Teknologi Pertanian, Universitas Jember \\ Jln. Kalimantan 37 Kampus Tegalboto, Jember 68121 \\ ${ }^{2}$ Magister Pengelolaan Sumber Daya Air Pertanian, Pascasarjana, Universitas Jember \\ Jln. Kalimantan 37 Kampus Tegalboto, Jember 68121 \\ Email: elida_novita.ftp@unej.ac.id
}

\begin{abstract}
Coffee pulp and coffee husk has nutrients content that can be utilized for plant growth. One of their utilization is as growing media called compost block. The purposes of this study were to know the macro nutrients content in the coffee solid waste compost and the influence of compost block utilization to the crop growth rate of cayenne pepper. The experimental design was a Completely Randomized Design $(C R D)$ with four treatments and three replications. The treatments were soil as control $(K)$, coffee pulp compost block (KOB), coffee husk compost block (KOK), and mixed compost block (KOC). The parameters measured in this study were plant height, number of leaves, leaf area, and the diameter of stem. Data analysis used Standard Error of Mean and presented in error bar. The results showed that mixed compost has the highest macro nutrients content. The content of macro nutrients in coffee pulp compost were 1,86\% of Nitrogen (N), 0,16\% of Phospor (P), and 1,39\% of Potassium (K); coffee husk compost were 1,68\% of $N, 0,11 \%$ of $P$, and 1,70\% of $K$; and also mixed compost were 3,22\% of N, 1,09\% of $P$, and 1,39\% of $K$. The mixed compost block treatment gives the best result to vegetative growth rate of cayenne pepper. The growth rate of plant height was 7,88 cm/week; number of leaves was 2 leaves/week; leaf area was $7,20 \mathrm{~cm}^{2} /$ week; and the diameter of stem was $0,03 \mathrm{~cm} /$ week.
\end{abstract}

Keywords : Coffee Pulp, Coffee Husk, and Compost Block

\section{PENDAHULUAN}

Pengolahan buah kopi terdiri dari dua proses, yaitu pengolahan basah dan pengolahan kering. Kedua proses ini dapat menghasilkan limbah padat berupa kulit kopi dengan proporsi total $41 \%$ yang terdiri dari kulit luar (pulp) 29\% dan kulit tanduk $\quad 12 \% \quad$ (Bressani, 1979:9). Kabupaten Jember merupakan salah satu daerah penghasil kopi utama di Jawa Timur. Menurut Badan Pusat Statistik (2016), produksi kopi di Kabupaten Jember pada tahun 2015 mencapai
24.697,56 ton. Besarnya produksi kopi tersebut berpotensi menghasilkan limbah kulit kopi sebanyak 1.012,6 ton.

Pada umumnya, limbah kulit kopi hanya digunakan sebagai pakan ternak atau dibuang begitu saja tanpa dilakukan pengolahan. Hal ini disebabkan karena rendahnya kesadaran masyarakat untuk menjaga lingkungan dari pencemaran limbah kopi, rendahnya pengetahuan dan ketrampilan masyarakat untuk mengolah limbah kopi menjadi kompos. Padahal limbah kulit kopi baik hasil olah basah 
maupun olah kering memiliki kandungan unsur hara yang dapat dimanfaatkan untuk kebutuhan tanaman. Menurut Dzung et al. (2013), kulit tanduk buah kopi memiliki kandungan nitrogen $(\mathrm{N})$ sebesar 1,27\%, fosfor (P) 0,06\% dan kalium (K) 2,46\%. Menurut Bressani (1979:21), limbah kulit luar (pulp) memiliki kandungan N 1,94\%, P 0,28\%, dan K 3,61\%. Berdasarkan kandungan unsur hara pada limbah kulit kopi tersebut, terdapat beberapa penelitian terdahulu yang menggunakan kulit kopi untuk dimanfaatkan sebagai bahan pembuatan kompos.

Menurut penelitian Berlian et al. (2015), penambahan kompos kulit kopi dengan berat 90 gram pada media tanam dapat berpengaruh sangat nyata terhadap parameter pertumbuhan cabai keriting. Penambahan kompos kulit kopi juga memberikan pertumbuhan dan perkembangan yang maksimum pada cabai keriting. Sedangkan penelitian Sahputra et al., (2013) menjelaskan bahwa pemberian kompos kulit kopi juga mampu meningkatkan jumlah daun hingga $24,96 \%$ dan diameter umbi sebesar $25,59 \%$ pada pertumbuhan bawang merah.

Limbah kulit kopi tidak hanya dimanfaatkan sebagai pupuk kompos, tetapi juga dapat dimanfaatkan sebagai media tanam untuk cabai rawit. Salah satu bentuk pemanfaatan kulit kopi sebagai media tanam cabai rawit adalah berupa kompos blok. Kompos blok merupakan produk inovasi yang dapat menggantikan kompos biasa, yang terkadang dalam pembuatan dan penggunaannya masih sangat terbatas dan kurang efektif. Pemanfaatan limbah kulit kopi menjadi kompos blok pertama kali diperkenalkan oleh Asmak Afriliana pada tahun 2010 (Maruli, 2010). Kompos blok tersebut memiliki kegunaan sebagai pupuk dan dapat dimanfaatkan sebagai tempat pembenihan bibit tanaman, serta membuat tanaman lebih baik pertumbuhannya karena jumlah daun yang muncul lebih banyak dan perakaran yang lebih kuat. Namun, kompos blok yang pernah dibuat hanya berasal dari limbah kulit kopi hasil olah kering saja.

Berdasarkan uraian di atas, pemanfaatan limbah kulit kopi sebagai kompos blok masih belum banyak dilakukan. Kompos blok tersebut belum pernah diteliti lebih lanjut secara ilmiah mengenai unsur hara yang terkandung di dalamnya. Oleh karena itu, tujuan penelitian ini yaitu mengetahui kandungan-kandungan unsur hara pada kompos blok dan pengaruh 
penggunaannya sebagai media tanam terhadap laju pertumbuhan vegetatif tanaman hortikultura. Hortikultura memiliki masa pertumbuhan yang lebih singkat dibandingkan tanaman jenis lainnya.

\section{METODOLOGI PENELITIAN}

\section{Waktu dan Tempat Penelitian}

Penelitian dilaksanakan

di

Laboratorium Teknik Pengendalian dan Konservasi Lingkungan, Jurusan Teknik Pertanian, Fakultas Teknologi Pertanian, Universitas Jember pada bulan Januari sampai dengan Maret 2017.

\section{Alat dan Bahan Penelitian}

Peralatan yang digunakan dalam penelitian ini antara lain ember, bak, pengepres kompos blok, kotak persemaian, kompor, panci, timbangan, $\mathrm{pH}$ meter, thermometer, paralon, dan hand sprayer. Bahan yang digunakan adalah limbah kulit kopi olah basah dan olah kering, tanah, EM-4, molasses, pupuk kandang, kanji, benih cabai sebagai tanaman untuk pengujian, dan air.

\section{Tahapan Penelitian}

Berikut ini merupakan tahapan penelitian yang dilakukan.

a) Pengumpulan Bahan Baku
Bahan baku limbah kulit kopi diperoleh dari pabrik pengolahan kopi di daerah Sidomulyo, Jember. Sedangkan bahan lainnya seperti EM4, molasses, dan bibit cabai rawit diperoleh dari toko pertanian setempat.

b) Pembibitan Cabai Rawit

Pembibitan dilakukan menggunakan nampan dengan ukuran $30 \times 20 \times 5$ $\mathrm{cm}^{3}$. Sebelum disemai, benih terlebih dahulu direndam dalam air hangat. Hal ini bertujuan agar calon tunas lebih cepat tumbuh. Penyemaian benih dilakukan dengan menebar benih secara merata pada media semai dengan jarak sekitar $3-6 \mathrm{~cm}$, kemudian benih ditutupi tipis-tipis dengan tanah. Penyiraman dilakukan setiap dua hari sekali secara merata ke seluruh permukaan tanah dan jumlah airnya disesuaikan dengan keadaan tanah.

c) Pengomposan Kulit Buah Kopi

Adapun prosedur pengomposan limbah kulit buah kopi, sebagai berikut:

1. Penyiapan limbah kulit kopi olah basah, olah kering, dan campuran keduanya masing-masing sebanyak $5 \mathrm{~kg}$; 
2. Llimbah kulit kopi kemudian dicacah menjadi ukuran lebih kecil untuk mempermudah proses dekomposisi dan dicampur dengan pupuk kandang;

3. Penambahan $100 \mathrm{ml}$ larutan EM-4 dan 2 sdm molase yang sudah dilarutkan ke dalam $5 \mathrm{~L}$ air kedalam limbah kulit kopi dan diaduk-aduk agar bahan tercampur rata;

4. Bahan-bahan tersebut dimasukkan ke dalam bak dan ditutup rapat dengan plastik selama 1 minggu agar terjadi fermentasi serta dilakukan homogenisasi biomassa dengan pengadukan;

5. Kompos sudah dapat digunakan setelah fermentasi matang. Sebelum dibentuk menjadi kompos blok, kompos kulit kopi terlebih dahulu dianalisis kandungan unsur haranya meliputi N, P, K, dan C.

d) Pengomposan Kulit Buah Kopi

Berikut ini merupakan tahapan penelitian yang dilakukan.

1. Disiapkan perekat berupa tepung kanji yang dilarutkan dalam air dan dipanaskan hingga mengental.
2. Disiapkan paralon berukuran 3 dim sepanjang $10 \mathrm{~cm}$ sebagai alat pencetak kompos blok.

3. Kompos kulit kopi selanjutnya diberi bahan perekat dan dicetak menggunakan paralon.

4. Kompos blok yang sudah jadi diberi lubang tanam dan dikeringkan di bawah sinar matahari hingga benar-benar kering.

e) Penanaman Cabai Rawit

Penanaman dilakukan dengan memindahkan bibit pada saat bibit telah memiliki $3-4$ helai daun. Penanaman bibit dilakukan pada sore hari. Hal ini dikarenakan pada siang hari penguapan air sangat besar dan dikhawatirkan akan berpengaruh terhadap tanaman yang baru saja dipindah.

f) Pengamatan Pertumbuhan Vegetatif Tanaman Cabai

Variabel pertumbuhan vegetatif tanaman yang diamati meliputi tinggi tanaman, jumlah daun, luas daun, dan diameter batang.

g) Pengukuran Laju Pertumbuhan Vegetatif Cabai Rawit

Pengukuran laju pertumbuhan dilakukan untuk mengetahui 
perbedaan pertumbuhan tanaman cabai rawit pada setiap parameter mulai minggu pertama hingga minggu kedelapan.

\section{Rancangan Percobaan}

Percobaan menggunakan Rancangan Acak Lengkap (RAL) dengan 4 perlakuan yaitu media tanah sebagai kontrol (K), kompos blok kulit kopi olah basah (KOB), kompos blok kulit kopi olah kering (KOK), dan kompos blok kulit kopi campuran olah basah dan olah kering (KOC). Masing-masing perlakuan dilakukan 3 kali pengulangan.

\section{Analisis Data}

Data dianalisis menggunakan Standar Error of Mean (SEM) untuk mengetahui perbedaan nilai rata-rata laju pertumbuhan cabai rawit. Hasil pengolahan data disajikan dalam bentuk grafik hubungan perlakuan dengan laju pertumbuhan tanaman cabai rawit.

\section{HASIL DAN PEMBAHASAN}

\section{Hasil Analisis Kandungan Unsur Hara}

Hasil analisis kandungan unsur hara pada kompos kulit kopi dan tanah yang ditunjukkan pada Tabel 1.

Tabel 1. Hasil Uji Laboratorium Kandungan Unsur Hara pada Tanah, Kompos Kulit Kopi Olah Basah, Kompos Kulit Kopi Olah Kering, dan Kompos Kulit Kopi Campuran.

\begin{tabular}{lllll}
\hline \hline Kandungan Unsur Hara & Tanah & KOB & KOK & KOC \\
\hline \hline N-Total (\%) & 0,19 & 1,86 & 1,68 & 3,22 \\
$\mathrm{P}_{2} \mathrm{O}_{5}(\%)$ & 0,21 & 0,16 & 0,11 & 1,09 \\
$\mathrm{~K}_{2} \mathrm{O}(\%)$ & 0,68 & 1,39 & 1,70 & 1,76 \\
C-Organik $(\%)$ & 2,15 & 29,60 & 25,48 & 33,58 \\
C/N Rasio & 11,00 & 16,00 & 15,00 & 10,00 \\
\hline \hline
\end{tabular}

Pada Tabel 1. dapat diketahui bahwa tanah yang digunakan sebagai media tanam kontrol memiliki kandungan unsur hara yang tergolong sangat rendah hingga rendah menurut Balai Penelitian Tanah (2005). Rendahnya kandungan unsur hara pada tanah dapat dipengaruhi oleh nilai $\mathrm{pH}$ tanah tersebut. Menurut Novizan (2002), unsur-unsur makro seperti N, P, $\mathrm{K}, \mathrm{Mg}, \mathrm{Ca}$, dan $\mathrm{S}$ lebih banyak tersedia di dalam larutan tanah ber-pH $6-7,5$. Pada $\mathrm{pH}$ lebih rendah atau lebih tinggi ketersediaan unsur hara tersebut menurun.

Menurut persyaratan teknis minimal pupuk organik padat berdasarkan Peraturan Menteri Pertanian Nomor 70 Tahun 2011, kompos yang baik memiliki kandungan $\mathrm{C}$-organik minimal 15\%, C/N rasio $15-25$, dan total unsur hara makro minimal 4\%. Berdasarkan Tabel 1., nilai 
C-organik pada ketiga jenis kompos kulit kopi telah memenuhi standar tersebut. Untuk nilai $\mathrm{C} / \mathrm{N}$ rasio, hanya kompos kulit kopi olah basah dan kompos kulit kopi olah kering saja yang memenuhi standar, sedangkan kompos kulit kopi campuran tidak memenuhi. Hal ini dikarenakan tingginya kandungan C-organik dan nitrogen pada kompos kulit kopi campuran, sehingga menyebabkan nilai $\mathrm{C} / \mathrm{N}$ rasio kecil.

Kandungan unsur hara makro total yang memenuhi standar hanya kompos kulit kopi campuran, yaitu sebesar 6,07\% . Tingginya kandungan unsur hara makro tersebut dikarenakan kulit kopi hasil olah basah dan olah kering pada dasarnya memiliki kandungan unsur hara berbeda. Ketika limbah kulit kopi dari kedua proses tersebut dicampur, akan menghasilkan kandungan unsur hara yang lebih tinggi. Penambahan EM-4 juga berpengaruh terhadap kandungan hara pada kompos. Hal ini dikarenakan EM-4 mengandung banyak mikroorganisme, terutama asam laktat, bakteri, serta ragi yang dapat meningkatkan ketersediaan unsur hara sehingga mudah diserap tanaman.

Kandungan unsur hara makro total pada kompos kulit kopi olah basah dan kompos kulit kopi olah kering tidak memenuhi standar karena nilainya kurang dari 4\%. Kompos kulit kopi olah basah memiliki kandungan unsur hara makro total sebesar $3,41 \%$. Proses pengomposan yang dilakukan menambah kandungan hara dalam jumlah yang sedikit, dikarenakan kulit kopi yang digunakan pada penelitian ini merupakan hasil proses pengolahan yang sudah cukup lama. Kondisi lingkungan yang tidak terkontrol menyebabkan kulit kopi olah basah memiliki kelembaban yang cukup tinggi akibat bercampur dengan air hujan. Menurut Indriani (2010), kelembaban yang tinggi menyebabkan mikroorganisme tidak berkembang atau bahkan mati, sehingga proses dekomposisi yang terjadi secara alami tidak berjalan dengan baik.

Kompos kulit kopi olah kering memiliki kandungan unsur hara makro total sebesar 3,49\%. Hasil penelitian Dzung et al. (2013) menunjukkan bahwa kulit kopi merupakan limbah pertanian yang kaya akan kalium, sehingga baik digunakan untuk proses pengomposan. Namun, kulit kopi olah kering memiliki kandungan lignin cukup tinggi yang dapat menghambat proses dekomposisi. Oleh karena itu, pada proses pengomposan kulit kopi ditambahkan larutan EM-4 karena 
mengandung bakteri asam laktat yang berfungsi untuk mempercepat perombakan bahan organik seperti lignin dan selulosa serta menekan bakteri pathogen dengan asam laktat yang dihasilkan.

Penggunaan kompos blok kulit kopi sebagai media tanam memiliki beberapa keuntungan, yaitu mengurangi penumpukan limbah kulit kopi, mengurangi penggunaan polybag sehingga lebih ramah lingkungan, dan efektif digunakan sebagai media tanam pada lahan sempit. Dengan adanya kompos blok, diharapkan dapat menjadi alternatif solusi dalam mengatasi permasalahan lahan pertanian yang semakin berkurang.

\section{Laju Pertumbuhan Vegetatif Cabai} Rawit

\section{Tinggi Tanaman}

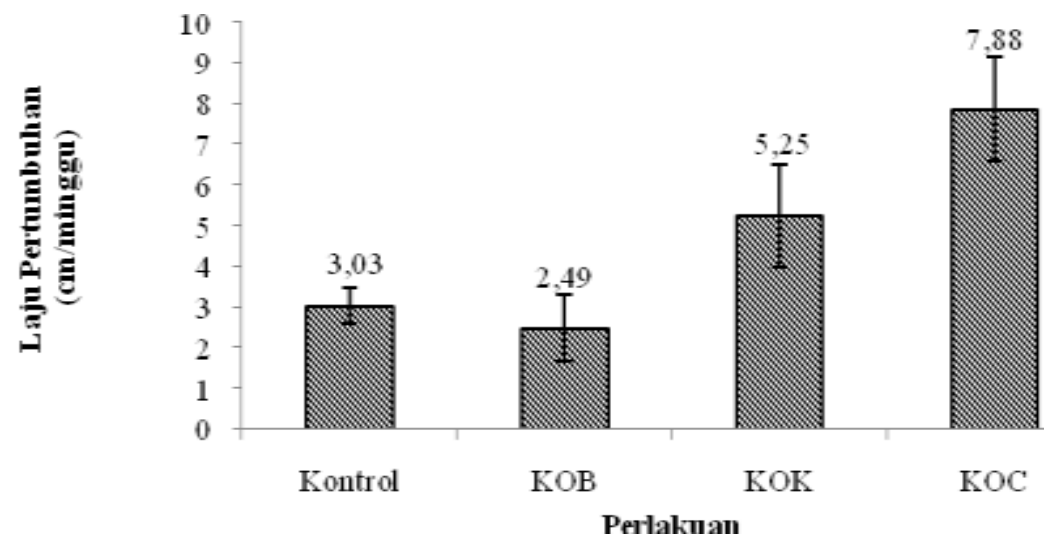

Gambar 1. Grafik Hubungan Perlakuan terhadap Laju Pertumbuhan Tinggi Tanaman Cabai Rawit 
Laju pertumbuhan tinggi tanaman terendah terdapat pada perlakuan kompos blok kulit kopi olah basah (KOB). Hal ini dikarenakan kulit kopi yang digunakan pada penelitian ini merupakan hasil proses pengolahan yang sudah cukup lama. Proses pengomposan yang dilakukan hanya menambah kandungan hara dalam jumlah yang sedikit, dan mengakibatkan penggunaannya sebagai media tanam tidak memberikan pertumbuhan yang maksimal. Gambar 1 juga dapat dilihat bahwa laju pertumbuhan tinggi tanaman pada perlakuan kontrol lebih tinggi dibandingkan KOB. Hal ini dikarenakan kompos kulit kopi olah basah belum terdekomposisi dengan sempurna, sehingga mikroorganisme pengurai yang terdapat pada kompos akan bersaing dengan tanaman dalam memperoleh unsur hara. Kondisi ini menyebabkan pertumbuhan tanaman pada KOB lebih lambat dibandingkan dengan kontrol. Berdasarkan Gambar 1, diketahui bahwa perlakuan kontrol tidak berbeda secara signifikan dengan perlakuan KOB. Hal ini dilihat dari error bar yang sedikit tumpang tindih. Namun, keduanya berbeda secara signifikan terhadap KOK dan KOC. Sedangkan perlakuan KOK dan KOC tidak terjadi tumpang tindih, sehingga kedua perlakuan berbeda secara signifikan.

\section{Jumlah Daun}

Grafik hubungan perlakuan terhadap laju pertumbuhan jumlah daun tanaman cabai rawit yang disajikan pada Gambar 2 . Laju pertambahan jumlah daun terbanyak terdapat pada perlakuan KOC yaitu 2 helai/minggu. Hal ini dapat dikarenakan perlakuan KOC memiliki kandungan $\mathrm{N}$ lebih tinggi dari pada ketiga perlakuan lainnya yaitu sebesar $3,22 \%$. Pertambahan daun pada setiap minggu dapat dipengaruhi oleh kandungan unsur $\mathrm{N}$ yang mampu diserap dengan baik oleh tanaman. Pada fase vegetatif, tanaman berkonsentrasi untuk menumbuhkan akar, batang, dan daun, sehingga diperlukan unsur nitrogen yang cukup. Hal ini sesuai dengan pernyataan Lingga (1992), bahwa nitrogen berperan dalam merangsang pertumbuhan tanaman secara keseluruhan, khususnya batang, cabang, dan daun. Nitrogen juga berperan dalam pembentukan zat hijau daun yang berguna dalam proses fotosintesis. 


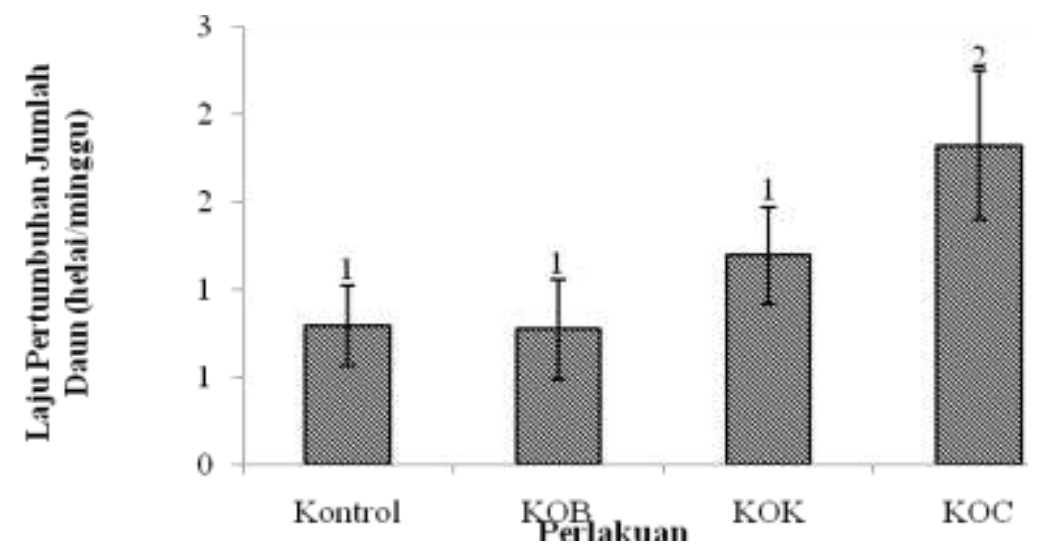

Gambar 2. Grafik Hubungan Perlakuan terhadap Laju Pertumbuhan Jumlah Daun Tanaman Cabai Rawit

Perlakuan kontrol, KOB, dan KOK memiliki laju pertumbuhan jumlah daun yang sama yaitu 1 helai/minggu. Hal ini dikarenakan ketiga perlakuan tersebut memiliki kandungan unsur hara yang hampir sama. Namun, kandungan unsur hara tersebut belum memenuhi standar, sehingga perlu penambahan nutrisi untuk membantu pertumbuhan daun tanaman. Berdasarkan error bar pada Gambar 2, klorofil tinggi, sehingga tanaman diketahui bahwa perlakuan kontrol, KOB, menghasilkan karbohidrat dalam jumlah dan KOK tidak berbeda secara signifikan. yang cukup untuk menopang pertumbuhan Namun, perlakuan kontrol dan KOB berbeda secara signifikan terhadap KOC. Sedangkan perlakuan KOK dan KOC tidak berbeda secara signifikan.

\section{Luas Daun}

Berdasarkan grafik pada Gambar 3, suplai $\mathrm{N}$ dan $\mathrm{P}$ yang cukup akan laju pertumbuhan luas daun paling tinggi menghambat pertumbuhan luas daunnya terdapat pada perlakuan KOC sebesar 7,20 dan mengakibatkan daun tumbuh $\mathrm{cm}^{2} /$ minggu. Hal ini dapat dikarenakan berukuran kecil. Berdasarkan error bar tanaman cabai rawit mendapatkan suplai unsur hara yang cukup, utamanya unsur nitrogen (N). Menurut Wijaya (2008), peran unsur $\mathrm{N}$ dalam tanaman yaitu mendorong pertumbuhan organ-organ yang berkaitan dengan fotosintesis yaitu daun. Tanaman yang cukup mendapat suplai $\mathrm{N}$ akan membentuk daun dengan helaian lebih luas dengan kandungan vegetatif. Laju pertumbuhan luas daun paling kecil terdapat pada perlakuan kontrol. Hal ini dikarenakan kandungan unsur hara pada media tanam kontrol paling rendah diantara ketiga perlakuan lainnya. Tanaman yang tidak mendapat 
pada Gambar 3 diketahui bahwa signifikan terhadap KOC, sedangkan perlakuan kontrol, KOB, dan KOK tidak perlakuan kontrol berbeda secara berbeda secara signifikan. Perlakuan KOB signifikan terhadap KOC.

dan KOK juga tidak berbeda secara

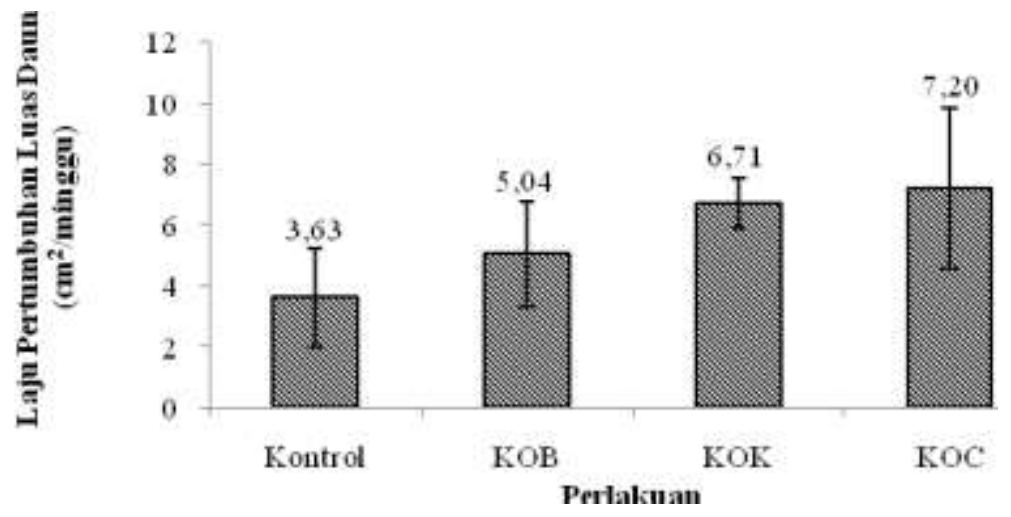

Gambar3.Grafik Hubungan Perlakuan terhadap Laju Pertumbuhan Luas Daun Tanaman Cabai Rawit

\section{Diameter Batang}

Berdasarkan grafik pada Gambar 4, batang pada setiap minggunya dapat diketahui bahwa perlakuan KOC memiliki terjadi karena kebutuhan unsur hara laju pertumbuhan diameter batang paling tanaman cabai rawit telah terpenuhi, besar yaitu $0,03 \mathrm{~cm} /$ minggu. Hal tersebut utamanya unsur nitrogen $(\mathrm{N})$. disebabkan karena kandungan unsur $\mathrm{N}$ pada KOC lebih tinggi daripada ketiga
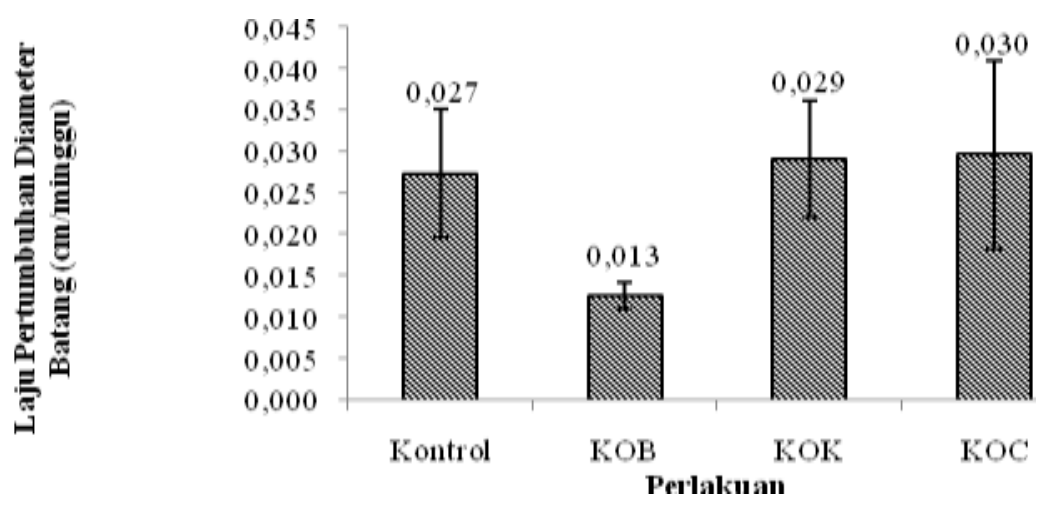

Gambar 4. Grafik Hubungan Perlakuan Terhadap Nilai Laju Pertumbuhan Diameter Batang Tanaman Cabai Rawit 
Lingga (1992) menyatakan bahwa nitrogen berperan dalam merangsang pertumbuhan tanaman secara keseluruhan, khususnya batang, cabang, dan daun Nitrogen juga berperan dalam pembentukan zat hijau daun yang berguna dalam proses fotosintesis. Perlakuan KOB menunjukkan hasil laju pertumbuhan diameter batang yang paling kecil yaitu $0,013 \mathrm{~cm} / \mathrm{minggu}$. Hal ini dapat terjadi karena tanaman kekurangan unsur $\mathrm{N}$ dan $\mathrm{P}$. Tanaman yang kekurangan unsur $\mathrm{N}$ dan $\mathrm{P}$ akan menyebabkan pertumbuhan terhambat dan batang yang kecil. Berdasarkan error bar pada Gambar 4, diketahui bahwa perlakuan kontrol, KOK, dan KOC tidak berbeda secara signifikan. Namun, ketiganya berbeda secara signifikan terhadap perlakuan KOB.

\section{KESIMPULAN}

Berdasarkan hasil dan pembahasan yang telah diperoleh, maka ditarik kesimpulan sebagai berikut:

a) Kandungan unsur hara makro (N, P, K) pada kompos kulit kopi olah basah yaitu $1,86 \% \mathrm{~N}, 0,16 \% \mathrm{P}$, dan $1,39 \% \mathrm{~K}$; kompos kulit kopi olah kering 1,68\% $\mathrm{N}$; 0,11 P; dan 1,70 K; serta kompos kulit kopi campuran olah basah dan olah kering 3,22\% $\mathrm{N} ; 1,09 \% \mathrm{P}$; dan $1,76 \% \mathrm{~K}$.

b) Perlakuan kompos blok kulit kopi campuran (KOC) memberikan hasil paling baik pada laju pertumbuhan vegetatif cabai rawit. Laju pertumbuhan tinggi tanaman sebesar 7,88 cm/minggu; laju pertumbuhan jumlah daun sebanyak 2 helai/minggu; laju pertumbuhan luas daun 7,20 $\mathrm{cm}^{2} /$ minggu; dan laju pertumbuhan diameter batang $0,03 \mathrm{~cm} /$ minggu.

\section{DAFTAR PUSTAKA}

Badan Pusat Statistik. 2016. Kabupaten Jember Dalam Angka 2016. Jember: BPS Kabupaten Jember

Balai Penelitian Tanah. 2005. Petunjuk Teknis Analisis Kimia Tanah, Tanaman, Air, dan Pupuk. Bogor: Balai Penelitian Tanah.

Berlian, Z., Syarifah, dan D. S. Sari. 2015. Pengaruh Pemberian Limbah Kulit Kopi (Coffea robusta L.) terhadap Pertumbuhan Cabai Keriting (Capsicum annum L.).Jurnal Biota, 1(1):22-32.

Bressani, R.1979. The by-products of coffee berries.dalam coffee pulp: composition, technology, and utilization. Editor J. E. Braham dan R. Bressani. Ottawa: Institute of Nutrition of Central America and Panama.

Hadisuwito, S. 2007. Membuat Pupuk Kompos Cair. Jakarta: Agromedia Pustaka.

Indriani, Y. H. 2010. Membuat Kompos Secara Kilat. Jakarta: Penebar Swadaya. 
Lingga, P. 1992. Petunjuk Penggunaan Pupuk. Jakarta: Penebar Swadaya.

Maruli, A. 2010.Limbah kopi antar mahasiswa ke jerman. http://www.antaranews.com/berita/2 27334/limbah-kopi-antarmahasiswake-jerman/2017.07.18.

Novizan.2002. Petunjuk Pemupukan Yang Efektif. Jakarta: AgroMedia Pustaka.

Peraturan Menteri Pertanian Nomor 70 Tahun 2011.Pupuk Organik, Pupuk Hayati dan Pembenah tanah.25 Oktober 2011.
Sahputra, A., A. Barus, dan R. Sipayung. 2013. Pertumbuhan dan produksi bawang merah (Allium ascalonicum L.) terhadap pemberian kompos kulit kopi dan pupuk organik cair. Jurnal Online Agroekoteknologi, 2(1):26-35.

Wijaya, K. A. 2008. Nutrisi Tanaman: Sebagai Penentu Kualitas Hasil dan Retensi Alami Tanaman. Jakarta: Prestasi Pustaka. 